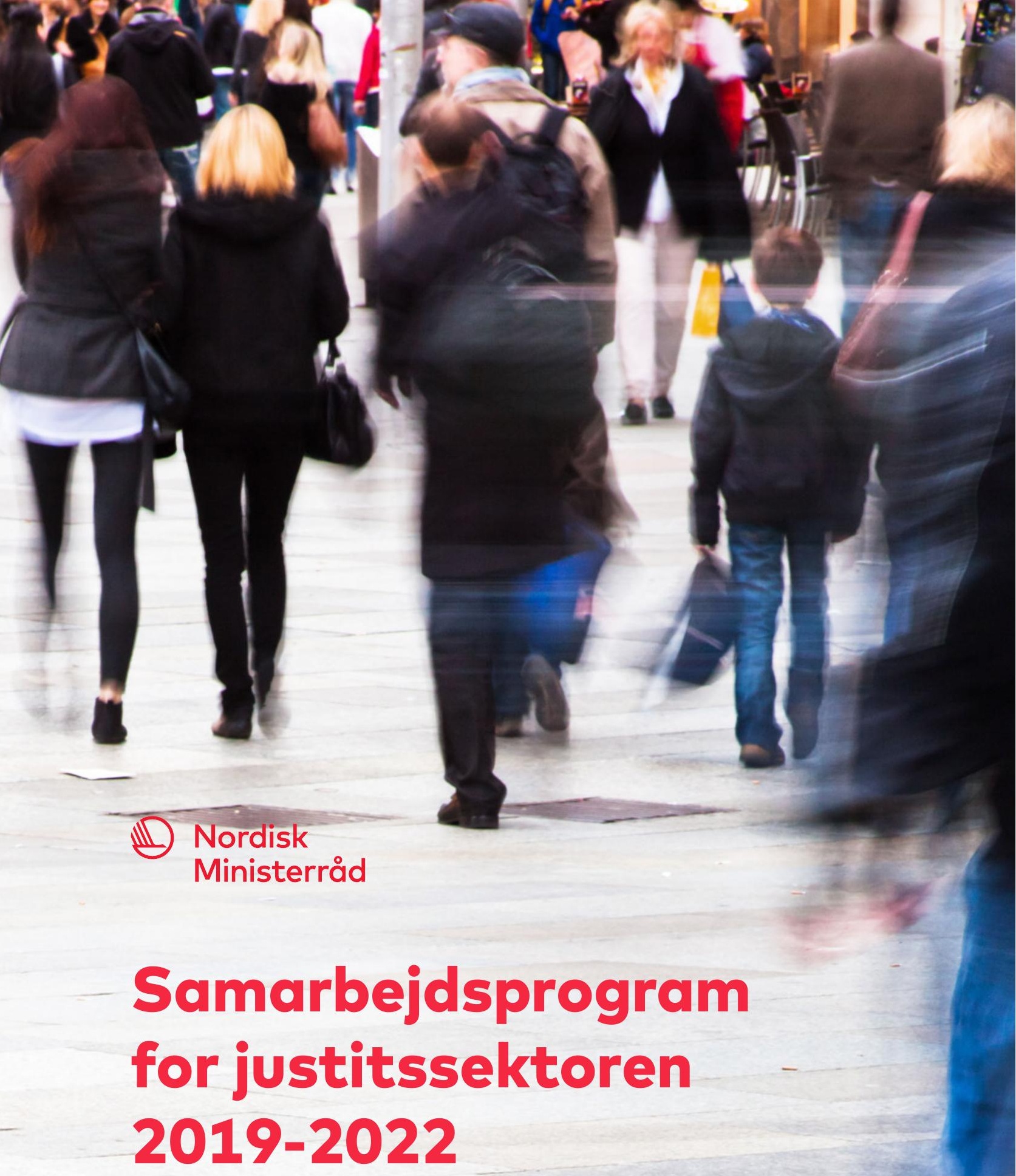


Samarbejdsprogram for justitssektoren 2019-2022

\section{PolitikNord 2019:717}

ISBN 978-92-893-6047-0 (PDF)

ISBN 978-92-893-6048-7 (EPUB)

http://dx.doi.org/10.6027/PN2019-717

(c) Nordisk Ministerråd 2019

Layout: Mette Agger Tang

Omslagsfoto: Scanpix.dk

\section{Det nordiske samarbejde}

Det nordiske samarbejde er en af verdens mest omfattende regionale samarbejdsformer. Samarbejdet omfatter Danmark, Finland, Island, Norge og Sverige samt Færøerne, Grønland og Åland.

Det nordiske samarbejde er både politisk, økonomisk og kulturelt forankret, og er en vigtig medspiller i det europæiske og internationale samarbejde. Det nordiske fællesskab arbejder for et stærkt Norden i et stærkt Europa.

Det nordiske samarbejde ønsker at styrke nordiske og regionale interesser og værdier i en global omverden. Fælles værdier landene imellem er med til at styrke Nordens position som en af verdens mest innovative og konkurrencedygtige regioner.

\section{Nordisk Ministerråd}

Nordens Hus

Ved Stranden 18

1061 København K

www.norden.org

Download og bestil nordiske publikationer: www.norden.org/nordpub 


\section{Samarbejdsprogram for justitssektoren 2019-2022}

\section{Indhold}

05 Forord

07 Indledning

09 Strategiske indsatsområder

12 Appendix 


\section{Forord}

Samarbejdet inden for justitssektoren skal bidrage til at opfylde den målsætning, som de nordiske statsministrene blev enige om i september 2016, om at Norden skal være verdens mest integrerede region.

Det retlige samarbejde i justitssektoren skal medvirke til at fremme grundlæggende fælles principper i nordisk lovgivning i overensstemmelse med det nordiske værdifællesskab. Samarbejdet er også et vigtigt element i det europæiske lovgivningsarbejde og ved gennemførelse af EU/EES retsakter og andre internationale forpligtelser. 


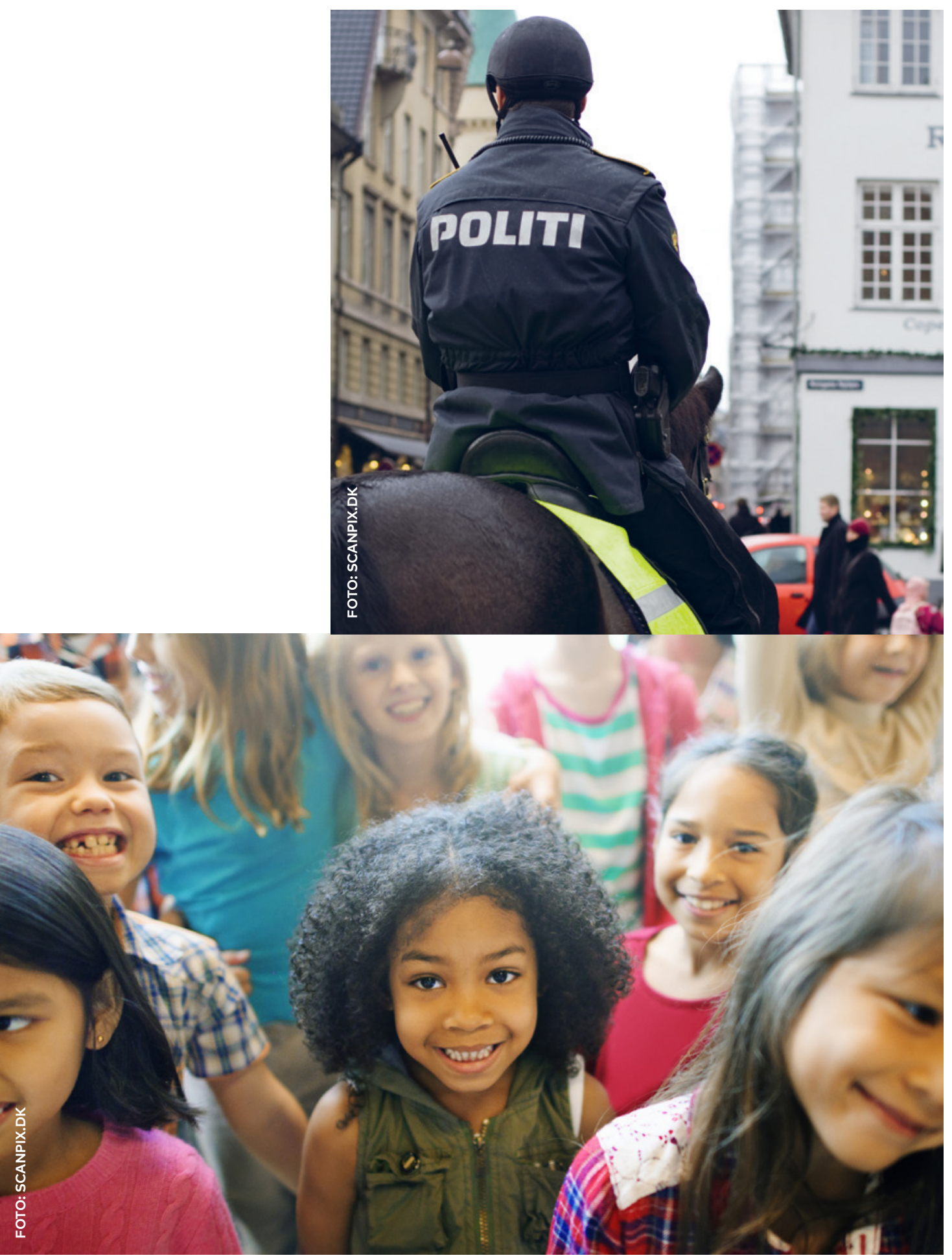




\section{Indledning}

\section{Det nordiske samarbejde}

Det nordiske samarbejde som omfatter Danmark, Finland, Island, Norge og Sverige samt Færøerne, Grønland og Åland blev formaliseret med oprettelsen af Nordisk Råd i 1952.

I 1962 underskrev landene Helsingforsaftalen som er det formelle retlige dokument, der regulerer det nordiske Samarbejde og i 1971 blev Nordisk Ministerråd oprettet for at varetage samarbejdet mellem de nordiske regeringer og den politiske ledelse i Færøerne, Grønland og Åland.

Det nordiske justitsministerielle samarbejde bygger på principperne i Helsingforsaftalen, de overordnede principper for det nordiske samarbejde og nærværende samarbejdsprogram. Samarbejdet suppleres efter behov med formandsskabsprogrammer og konkrete initiativer.

\section{Samarbejdsområder}

Justitssektorens samarbejdsområde omfatter de sagsområder, som i de fleste nordiske lande henhører under justitsdepartementerne.
Justitssektoren arbejder med områder indenfor det offentligretslige område, blandt andet strafferet og procesret, domstolssystemet, kriminalitets-og terrorforebyggelse, beskyttelse af ofre, politisamarbejde og spørgsmål om asyl, immigration, diskrimination, grundlæggende rettigheder og menneskerettigheder. Også andre offentligretlige områder såsom forvaltningsret, offentlighedens ret til aktindsigt og lovgivningen angående persondatabeskyttelse indgår i justitssektorens samarbejdsområder.

Justitssektoren arbejder også med områder indenfor privatretten, såsom familieret, formue- og aftaleretten og forbrugerret.

I justitssamarbejdet prioriteres sager, hvor der kan opnås nordisk nytte. Dette indebærer, at der lægges vægt på, om der gennem fælles eller ensartede nordiske aktiviteter og løsninger, så som forskning, kan opnås bedre resultater end hvis det samme forgår i nationalt regi. Det indebærer videre, at der lægges vægt på, at nordisk kompetence styrkes og at kontakter og forbindelser mellem de nordiske lande forbedres. 

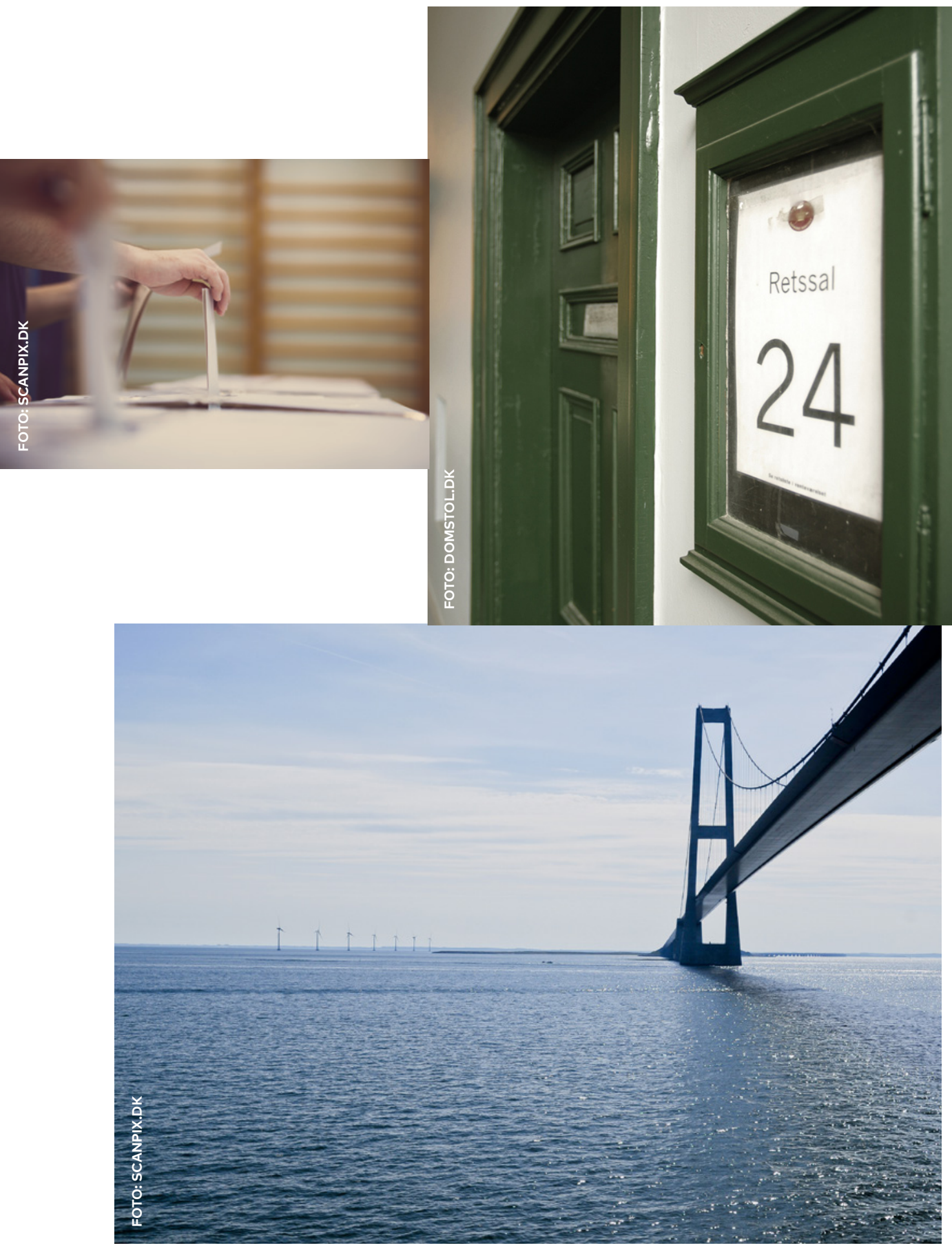


\section{Strategiske indsatsområder}

\section{Sikring af retssikkerheden}

Det nordiske samarbejde inden for justitssektoren skal bidrage til at sikre de demokratiske beslutningsprocesser i de nordiske lande og til at varetage retssikkerheden for borgere og virksomheder.

Samarbejdet skal bidrage til en bæredygtig samfundsudvikling, der lever op til FN's Agenda 2030 mål.

Sektoren vil derfor tilstræbe, hvor det er relevant og kan skabe en merværdi, at alle projekter eller initiationer, som sektoren støtter, knytter an til at opfylde et af målene i FN's Agenda 2030, herunder mål 16 om fred, retfærdighed og stærke institutioner, hvor alle gives adgang til retssikkerhed.

\section{Nordisk retsenhed og nytte}

Helsingforsaftalen sigter mod indbyrdes samordning på justitsområdet. Dette indebærer imidlertid ikke nødvendigvis, at lovgivningen skal være identisk. Nordisk retsenhed omfatter også opnåelse af en fælles struktur og fælles bærende retlige principper for lovgivningen. Behovet, omfanget og karakteren af justitssamarbejdet varierer på de forskellige retsområder.
Om det retslige samarbejde fastsætter Helsingforsaftalen blandt andet følgende:

Artikel 4

De kontraherende parter skal fortsætte lovgivningssamarbejdet med henblik på at opnå den størst mulige overensstemmelse på privatrettens område.

\section{Artikel 5}

De kontraherende parter bor tilstræbe ensartede bestemmelser om forbrydelser og strafferetlige retsfølger. Med hensyn til forbrydelser, der er begået i et nordisk land, bør efterforskning og strafforfølgning $i$ videst mulig udstrækning kunne finde sted også $i$ et andet nordisk land.

En vigtig målsætning for justitssamarbejdet er, at landenes lovgivning og anden regulering har et indhold og en udformning som er tilgængelig for borgerne samt at borgere og virksomheder kan bevæge sig frit over grænserne i Norden uden unødige grænsehindringer. Det påhviler landene i så høj grad som muligt at sikre, at ny lovgivning ikke medfører nye grænsehindringer. Eksempevis bør det ved gennemførelse af EU/ EØS-regulering og andre internationale forpligtelser i særlig grad tilstræbes, at 
der opnås retsenhed for at undgå, at der skabes nye grænsehindringer.

I det lovforberedende arbejde bør landene således, når det er relevant, indhente information om tilsvarende lovgivning i de øvrige nordiske lande og for at bidrage til kendskabet til nordisk lovgivning, som er en forudsætning for nordisk retsenhed, bør lovforslag, når det er relevant, indeholde en redegørelse for tilsvarende lovgivning i de øvrige nordiske lande.

\section{Forebyggelse af kriminalitet}

De nordiske lande står på mange områder over for de samme udfordringer for så vidt angår forebyggelse af kriminalitet og terror, som ikke sjældent har en grænseoverskridende karakter. Det samme gælder hvad angår bekæmpelse af menneskehandel, seksuelle overgreb mod personer på internettet samt andre seksuelle forbrydelser.

Et tæt nordisk samarbejde er derfor af stor betydning for de nordiske landes mulighed for at håndtere disse udfordringer i fremtiden.

Det gælder bl.a. et nordisk politisamarbejde, men også udveksling af viden om lovgivningsinitiativer, samt finansiering af udredninger inden for de områder, som sektoren arbejder med.

Samarbejdet skal forbedre kontakten og forbindelserne mellem de nordiske lande, og bidrage til at styrke landenes kompetencer inden for aktuelle områder. Som et konkret eksempel kan nævnes, at sektoren beskæftiger sig med at bekæmpe seksuelle overgreb mod børn. 


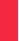




\section{APPENDIX}

\section{Samarbejdets operationalisering}

\section{Om samarbejdsprogrammer i Nordisk Ministerråd}

Samarbejdsprogrammet er styrende for sektorens virksomhed, men skal også ses i sammenhæng med andre styrende dokumenter i Nordisk Ministerråd, herunder vision for det nordiske regeringssamarbejde (sammen er vi stærkere), tværgående strategier samt de nationale formandskabsprogrammer.

\section{Håndtering af tværgående strategier}

Det er besluttet i Nordisk ministerråd at ligestillingshensyn, et hensyn til børn og unges rettigheder og et holdbarhedsperspektiv skal integreres i al ministerrådets arbejde. Dette indebærer bl.a. at disse perspektiver skal indgå i vurderingen af ansøgninger om tildeling af projektmidler.
Som et konkret eksempel der angår spørgsmålet om ligestilling, kan nævnes sektorens samarbejde angående bekæmpelsen af seksuelle forbrydelser.

I organiseringen af det nordiske justitssamarbejde tilstræbes desuden, i overensstemmelse med de nordiske samarbejdsministres retningslinjer for ligestilling, at begge køn repræsenteres med mindst $40 \%$ i arbejdsgrupper og lignende.

For så vidt angår børne- og ungeperspektivet kan nævnes samarbejdet om bekæmpelse af seksuelle overgreb på børn og unge på internettet

Endelig kan for så vidt angår spørgsmålet om bæredygtighed, nævnes, at sektoren vil tilstræbe - når det er relevant - at de projekter og initiativer, som sektoren

\begin{tabular}{|l|l|l|}
\hline Styringsdokument & Målgruppe & Tidsperiode \\
\hline $\begin{array}{l}\text { Samarbejdsministrenes } \\
\text { visionsdeklaration }\end{array}$ & Nordisk Ministerråd & Ingen slutdato \\
\hline Tværgående strategi & Nordisk Ministerråd & Op til 6 år \\
\hline Samarbejdsprogram & Sektorspecifik & 4-årig \\
\hline Formandskabsprogram & Nordisk Ministerråd & 1-årig \\
\hline
\end{tabular}


støtter, knytter an til at opfylde et af målene i FN's Agenda 2030.

\section{Øvrige strategiske platforme}

\section{Dialog med Nordisk Råd}

De nordiske justitsministre søger dialog med Nordisk Råd i spørgsmål af fælles interesse, herunder i forbindelse med udarbejdelse og revidering af samarbejdsprogrammet.

\section{Samarbejde med de baltiske stater} De nordiske justitsministre mødes med deres kolleger fra Estland, Letland og Litaven mindst hvert andet (2) år. Der er nedsat en kontaktgruppe (Nordic Baltic Contact Group) som mødes efter behov og som har sit eget arbejdsprogram.

Ordførerskabet roterer mellem landene, og sekretariatsfunktionen varetages af Nordisk Ministerråds sekretariat.

Samarbejdet bygger på en opfattelse af, at et tæt regionalt samarbejde er vigtigt indenfor EU og i forhold til tredjelande.

\section{Samarbejde hvad angår andre} internationale fora

Det indgår i det nordiske justitssamarbejde at fremme nordiske kontakter, diskussioner og efter behov samordning på embedsmandsniveau samt på politisk niveau i forbindelse med forhandlinger i andre internationale fora, eksempelvis FN og Europarådet.

I det nordiske samarbejde inden for justitssektoren indgår også at samarbejde ved udpegning af repræsentanter i internationale organer, når det ikke er muligt for alle nordiske lande at være repræsenteret samtidig.

Sektoren vil derfor tilstræbe at alle projekter eller initiationer, som sektoren støtter, knytter an til at opfylde et af målene i FN's Agenda 2030 mål, herunder mål 16 om fred, retfærdighed og stærke institutioner, hvor alle gives adgang til retssikkerhed.

\section{Andet nordisk retligt samarbejde} I justitssektoren er der to arbejdsgrupper, der består af embedsmænd fra de nordiske lande, som behandler henholdsvis familieretslige og strafferetslige spørgsmål.

Arbejdsgrupperne kan søge justitssektoren om midler til at afholde møder og rapporterer, hvis det er relevant, fra møderne. 
Udover det nordiske samarbejde i Nordiske Ministerråd foregår der et løbende praktisk samarbejde inden for hele justitssektoren.

På administrativt niveau afholdes der bl.a. kontaktmøder mellem de nordiske landes domstolsadministrationer, rigsadvokaterne, rigspoliticheferne i Norden og Kriminalforsorgen.

\section{Organisering i sektoren}

Justitsministerrådet og embedsmandskomiteen

Justitsministrene (MR-LOV) har det overordnede ansvar for samarbejdet. På deres årlige møde behandler ministrene politisk aktuelle sager af fælles nordisk interesse med henblik på at indlede et nordisk samarbejde indenfor nye retlige områder eller med henblik på i øvrigt at finde fælles nordiske løsninger.

Nordisk embedsmandskomité for justitssamarbejdet (EK-LOV) består af ledende embedsmænd med ansvar for justitsog lovgivningsspørgsmål i de nordiske justitsministerier. Komiteen forbereder og følger op på justitsministrenes årlige møde. Komiteen initierer endvidere nye projekter. Ved møderne i embedsmandskomiteen udveksler landende desuden information om ny lovgivning, retspraksis andre aktuelle retslige spørgsmål.
Justitsministrene eller embedsmandskomiteen har mulighed for at beslutte at nedsætte faste eller ad hoc arbejdsgrupper. I sådanne tilfælde udarbejder embedsmandskomiteen mandat og træffer afgørelse om eventuelt budget for sådanne arbejdsgrupper.

Embedsmandskomiteen samarbejder med Nordisk Ministerråds andre embedsmandskomiteer.

\section{Formandskabet}

Det kommende formandsskabsland præsenterer senest på embedsmandskomiteens 3. møde i året før formandsskabsperioden sine foreløbige planer for aktiviteter og initiativer for justitssektoren i formandsskabsperioden med henblik på en drøftelse i embedsmandskomiteen.

Det kommende formandsskabsland præsenterer i den forbindelse også, hvilke projekter, seminarer, udredninger m.v. der agtes gennemført og de tilhørende økonomiske rammer.

\section{Budget}

På det 1. årlige møde i embedsmandskomiteen drøftes det efterfølgende kalenderårs budget, herunder mål med tilhørende aktiviteter der ønskes prioriteret. 
Embedsmandskomiteens drøftelser af budgettet skal være afsluttet i så god tid, at resultatet heraf kan indgå $i$ Nordisk Ministerråds generalsekretærs forberedelse af et samlet budgetforslag for Nordisk Ministerråd.

\section{Anvendelse af projektmidler}

Justitsministrene eller embedsmandskommiteen kan inden for den årlige budgetramme støtte finansieringen af konferencer, seminarer, forskning, studier m.v. af særlig relevans for justitssektoren.

Embedsmandskomiteen følger de overordnede retningslinjer for anvendelse af Ministerrådets projektbudget.

Efter ansøgning kan der bevilges midler til eksterne projekter, såfremt bl.a. kriteriet om "nordisk nytte" er opfyldt.

Herudover har embedsmandskomiteen besluttet, at ca. 100.000 DKK afsættes til aktiviteter inden for rammerne af samarbejdet med Estland, Letland, Litaven.

Nordisk Ministerråds standardvilkår for projektkontrakter finder anvendelse ved justitssamarbejdets anvendelse af projektmidler.

\section{Afrapportering}

Rapportering af resultater og effekter af projekter sker ved hjælp af minister- rådets skema for statusrapportering. Endvidere bliver aktører, der modtager midler fra sektoren, til projekter og andre initiativer anmodet om at indlevere en kort beskrivelse af resultatet og effekterne af disse initiativer.

I det omfang det er relevant, fremlægges resultaterne af arbejdet for justitsministrene på det årlige justitsministermøde 


\section{APPENDIX}

\section{Håndtering af EU-relaterede sager}

\section{Samarbejds- programmets evaluering}

Justitssamarbejdet samarbejder om at vurdere konsekvenserne af EU/EØSretsakter så tidligt som muligt i EU's beslutningsproces. De vigtigste forslag til EU/EØS-retsakter gennemgås efter behov af embedsmandskomiteen for at se, om der er grundlag for nordiske drøftelser i forbindelse med en retsakts udarbejdelse eller ved implementering af retsakten i national lovgivning.

Ved gennemførelse af EU/EØS-retsakter kan man benytte sig af muligheden for erfaringsudveksling og arbejdsbesparelser $f x$ ved fælles udredninger. Det uformelle samarbejde mellem embedsmænd og myndigheder bør fastholdes og udvikles.

Det er ikke nødvendigt, at der vælges de samme lovgivningsløsninger $\mathrm{i}$ samtlige nordiske lande, men det har betydning, at der er enighed om forståelsen og fortolkningen af de pågældende fællesskabsretsakter i de nordiske lande.
Dette samarbejdsprogram skal evalueres og revideres senest i 2022. 


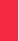




\section{Nordisk Ministerråd \\ Nordens Hus \\ Ved Stranden 18 \\ 1061 København K \\ www.norden.org}

\section{Nordisk samarbejdsprogram for justitssektoren 2019-2022}

Det nordiske samarbejde som omfatter Danmark, Finland, Island, Norge og Sverige samt Færøerne, Grønland og Åland blev formaliseret med oprettelsen af Nordisk Råd i 1952.

10 år senere i 1962 underskrev landene Helsingforsaftalen som er det formelle retlige dokument der regulerer det nordiske samarbejde. I 1971 blev Nordisk Ministerråd oprettet for at varetage samarbejdet mellem de nordiske regeringer og den politiske ledelse på Færøerne, Grønland og Åland.

Justitssektorens samarbejde varetages af de nordiske justitsministre. Det bygger på principperne i Helsingforsaftalen, de overordnede principper for det nordiske samarbejde og nærværende samarbejdsprogram. De strategiske indsatsområder for de nordiske justitsministres samarbejde i perioden 2019-2022 omfatter sikring af retssikkerheden, nordisk retsenhed og nordisk nytte. Samarbejdet har også et særskilt fokus på forebyggelse af kriminalitet og terror, som ikke sjældent har en grænseoverskridende karakter. 